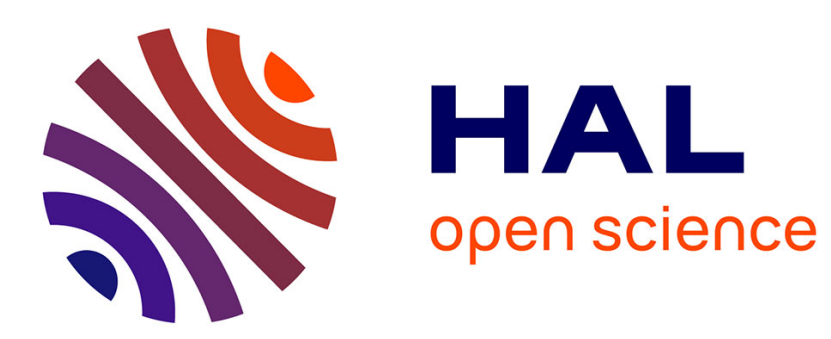

\title{
Multiracial versus Collective Black Categories
}

Stanley R. Bailey, Edward E. Telles

\section{To cite this version:}

Stanley R. Bailey, Edward E. Telles. Multiracial versus Collective Black Categories. Ethnicities, 2006, 6 (1), pp.74-101. 10.1177/1468796806061080 . hal-00571855

\section{HAL Id: hal-00571855 https://hal.science/hal-00571855}

Submitted on 1 Mar 2011

HAL is a multi-disciplinary open access archive for the deposit and dissemination of scientific research documents, whether they are published or not. The documents may come from teaching and research institutions in France or abroad, or from public or private research centers.
L'archive ouverte pluridisciplinaire HAL, est destinée au dépôt et à la diffusion de documents scientifiques de niveau recherche, publiés ou non, émanant des établissements d'enseignement et de recherche français ou étrangers, des laboratoires publics ou privés. 


\title{
Multiracial versus collective black categories
}

\section{Examining census classification debates in Brazil}

\author{
STANLEY R. BAILEY \\ University of California, Irvine
}

\section{EDWARD E. TELLES}

University of California, Los Angeles

\begin{abstract}
Current census debates in Brazil surrounding Brazilian race categories center on two contrasting proposals: the adoption of the multiracial moreno term vs. the use of the collective black classification negro. Those proposing the former base their argument on the right to self-classify according to one's own sense of identity. Proponents of the negro category contend that it would be most efficient for redressing racial discrimination. We examine the meaning and saliency of these categories and explore the possible consequences of their adoption. Using national survey data, we demonstrate how education, age, color, sex and local racial composition structure the choices of moreno and negro over official census terms. Findings include a negative correlation between education and the choice of moreno, while the opposite is true for negro. In addition, an age effect on both categories suggests a popular shift in racial labeling away from official census terms. We note that similar issues structure current census debates in the USA.
\end{abstract}

KEYWORDS census categories $\bullet$ multiracial $\bullet$ racial identities $\bullet$ racism

The question on race in the Brazilian census employs a three-category system to represent the black/white color continuum using the terms white, brown, and black. ${ }^{1}$ However, researchers debate the usefulness of these categories largely from two opposing perspectives (Nobles, 2000, 2002; Schwartzman, 1999). On the one hand, important percentages of Brazilians actually prefer to describe themselves using the non-census classification moreno. This category represents an ambiguous 'brownish' color that embodies the idea of racial mixture. A group of researchers (Byrne et al., 
1995; Harris et al., 1993, 1995) argues that this category is highly salient and that it should be included in the census in order to respect 'the right to self-identification' (Harris et al., 1995: 1614). On the other hand, black activists, other academics and sectors of the federal government have proposed a very different change in census classification to include the term negro, the rough equivalent of the US term 'black', in a white vs. negro classification scheme (Bertulio, 1997; Brasil, 1996). Although negro is not widely used as a term for self-identification among non-white Brazilians, they argue that institutionalizing this less ambiguous category would aid in making more visible the reality of racial inequality in Brazil and better enable its redress.

In preparation for the 2000 US Census, the proposed addition of a multiracial category fueled similar debates (Perlmann and Waters, 2002). On the one hand, proponents of the added category argued strongly that the right to self-identify is inalienable and that intermarriage in the USA has led to a situation in which so-called monoracial terms, i.e. those recognizing a single racial heritage (Farley, 2002b; Harris and Sim, 2002), may no longer be appropriate (Daniels, 2002; Snipp, 2002). On the other hand, strong opponents such as the National Association for the Advancement of Colored People (NAACP) and the Congressional Black Caucus argued that the institutionalization of multiracialism could undermine the state's ability to monitor racial discrimination and administer race-targeted intervention (Harrison, 2002; Skerry, 2002). Although the category was not added, the divergent groups compromised by allowing respondents to mark more than one race in the 2000 US Census.

In both Brazil and the USA, the census debates pit the right to selfidentify against the need to monitor and redress racial discrimination (Nobles, 2002; Skerry, 2002). The tension regarding self-identification flows from the fact that there are no unambiguous scientific criteria with which to classify individuals into one racial group or another (Hirschman et al., 2000). The contemporary standard of employing self-identification in censuses as opposed to interviewer-classification reflects an understanding that people are racially what they say they are (Perlmann and Waters, 2002). However, historic and contemporary racial discrimination is based centrally on other-classification (Snipp, 2002; Telles and Lim, 1998). Furthermore, race-targeted policies rely on discrete categories (Persily, 2002; Telles, 2004).

The tensions between multiracial and monoracial perspectives in both the USA and Brazil prompt new questions. What does it mean to be multiracial as opposed to self-classifying according to a single racial heritage (Daniels, 2002; Harris and Sim, 2002)? What are the sources of variability between these two classification schemes (Farley, 2002a, 2002b; Harris and Sim, 2002)? Will multiraciality make it difficult to monitor discrimination and disable race-targeted intervention, as some scholars 
argue (Harrison, 2002; Skerry, 2002; Spencer, 1999)? Finally, does official census naming simply reflect racial demographics or does it actually create new categories of persons (Jacobson, 2002; Starr, 1987)?

In this article, we explore these questions in the census debate between the use of a multiracial category versus a collective black label in Brazil. We first examine the popular meanings of the moreno and negro classifications that diverging groups of researchers propose as possible census categories. Employing national survey data, we document the saliency of these terms in the Brazilian population. Next, we examine the propensities to classify in the moreno and negro categories compared to the official census terms in order to locate the sources of variability between multiracial and collective black classification schemes. Specifically, how do education, age, sex, color, and local racial composition structure the choice of these terms? Subsequently, we discuss the possible usefulness of these terms for monitoring/redressing racial inequality and whether official census naming reflects or creates social groupings. We believe the Brazilian case has much in common with the US debate between multiracial and monoracial classification schemes, making a comparative perspective especially appropriate (Nobles, 2002; Perlmann and Waters, 2002).

\section{BRAZILIAN RACIAL CATEGORIES}

\section{The official census categories}

The Brazilian Institute of Geography and Statistics (IBGE) is the governmental agency responsible for designing and collecting the decennial population census. Until the 1991 Census, the IBGE asked census respondents, 'What is your color (cor)?' For the 1991 Census, the question read 'What is your color or race (raça)?' Since 1940, the IBGE has used the categories white, brown, black, yellow (amarelo, i.e. of some Asian descent), and added the Indigenous (indigena) category in the 1991 census. According to the 2000 Brazilian census, the racial or color composition of the population is 54 percent white, 39 percent brown, 6 percent black, one percent Asian and Indigenous combined. Self-identification has been the official method for recording racial category membership in Brazil since 1950 (Telles, 2002).

Unlike the USA, color or race in Brazil refers primarily to appearance rather than descent. For example, white persons in Brazil may have black ancestors while in the USA, a tradition of hypodescent generally defines whites as persons with no black precursors (Harris, 1964). Furthermore, although color or race in Brazil refers primarily to one's skin tone, hair texture and color, and facial features, it may be influenced by social factors 
such as one's education, wealth and gender as well as the context of social interaction (Harris, 1964; Pacheco, 1987; Telles, 2002).

Brazil has conducted 11 censuses since its first in 1872 and a race or color question has been asked in all but three, in 1900, 1920 and $1970 .^{2}$ One of the factors influencing the exclusion of the question in the 1970 Census, when the country was ruled by a military dictatorship, was the argument that in Brazil there is no race problem - hence, no reason to ask (Schwartzman, 1999). However, due to the insistence of academics and activists, the question was reinstated in the 1980 census. Since then, researchers have used census data to extensively document stratification along color lines in that context (e.g. Hasenbalg, 1985; Lovell, 1999; Telles, 2004). Notwithstanding, researchers debate whether or not the traditional census terms should be modified (Schwartzman, 1999). In preparation for the 2000 Census, this debate reappeared in exchanges involving black movement leaders, the director of the IBGE and a handful of academics. ${ }^{3}$ We briefly address the meaning and saliency of the proposed terms moreno and negro.

\section{Moreno: Ambiguity and multiracialism}

The term moreno is emblematic of the fluidity of the Brazilian system. Field researchers have found the term ambiguous enough to substitute for almost any other color category (Harris, 1964; Sansone, 1993). Its connotations include (1) light skinned persons with dark hair (Hutchinson, 1957); (2) a person of mixed race or parentage who generally has brunet hair (Wagley, 1963); and (3) a dark-skinned person (Levine, 1979). In her study of a neighborhood in Rio de Janeiro, Pacheco (1987) found widespread use of this term and suggested that its popularity flows from the way it enables residents to downplay racial differences. 'We are all morenos around here' and similar expressions were voiced by several informants as if moreno referred to an all-inclusive identity unbounded by rigid racial specificities. Sansone (1993: 164) reports: 'In fact, the term moreno is so popular that even persons whom the interviewer and other respondents would consider white prefer to call themselves morenos.'

Further testifying to the label's saliency, a 1976 national survey revealed that 34.4 percent of Brazilians chose moreno in an open-ended question, the second most common response after white (41.9\%) (Oliveira et al., 1985). Harris et al. (1993) found that if the moreno category was substituted for the brown term of the census, ${ }^{4}$ fully 63 percent of residents of a small town would be classified as moreno compared to 32 percent using the brown (pardo) category. Harris and his colleagues argue for an emic approach to the formulation of census categories, where 'racial identity is established by eliciting respondents' categorizations of themselves or of others using terms that respondents regard as appropriate' (Harris et al., 1993: 453). Moreover, 
they state that it is 'a matter of civil rights that individuals be permitted to categorize themselves and their children according to their own sense of identity' (p. 459). Based on their findings, they recommend moreno's inclusion in the national census.

What lies behind the popularity of the moreno classification? For some who find it favorable, it expresses 'Brazilianness,' as envisioned by Gilberto Freyre (1946). Confronted with scientific racism's belief that 'mixed' blood created degeneracy, this towering figure in the formation of Brazilian national ideology proposed instead that 'cross-breeding' produced hybrid vigor in humans. This enabled a bright future for Brazil with its large proportion of persons with varying degrees of African descent. By emphasizing the special character and uncommon flexibility of Portuguese colonizers that made possible extensive miscegenation among African, European, and indigenous peoples, Freyre claimed that Brazilians were becoming a new race, or a metarace, which he describes as a moreno people (Bailey, 2004; Freyre, 1979, Telles, 2004). Indeed, he stated that moreno is the only response category necessary when asking Brazilians about color (Freyre, 1979).

\section{Negro: Racial affirmation and the collective black category}

Unlike the term moreno, which seems to describe nearly all of the Brazilian population, the term negro is intended for persons of 'discernible' African origin. Sansone's (1993,1995,2003) extensive ethnographic studies examine the popular understanding of the negro and the census black (preto) categories in Brazil. Although both terms translate roughly as 'black', they differ in their connotations. Negro was 'originally a very offensive term that in the last decades became a term for ethnic affirmation' while black (preto) is a 'traditional term that refers primarily to color' (Sansone, 1995: 72). Negro movement members have made the distinction between the 'common black' or preto and the 'Africanized black' or negro (Barcelos, 1999: 163$).^{5}$

Two separate ethnographic studies of Rio de Janeiro, one conducted during the 1980s and the other in the 1990s, suggest a changing popularity of the term negro. The 1980s study found that the negro category retained a negative quality, and that it was rarely used in face-to-face interaction in the local community, among friends and acquaintances, or in family circles. In those contexts, 'relational terms' ranging from light (claro) to dark (escuro) and sometimes qualified with the adjectives 'more' (mais), 'very' (bem), and 'definitely' (mesmo), are preferred to the oppositional terms negro and white. However, Sheriff (2001) documents a changing 'discourse of race' in which nearly all of the inhabitants of the shantytown she studied in Rio were aware of the logic of a non-white/white bi-polar racial distinction in discussions concerning prejudice and discrimination, at the same 
time that negro continued to have negative connotations in popular discourse. Indeed, we find that the popular use of the term negro has increased six-fold over a recent twenty year period, based on the 1976 National Household Survey (PNAD) and results from our 1995 data. Only 0.5 percent of the Brazilian population chose negro in 1976, while 2.9 percent chose the term in 1995.

The growing popularity of negro in certain discursive realms is related in part to the growing influence of the negro movement. It has sought to raise racial consciousness through promoting a collective black (negro) identity. Studies reveal that individuals self-classifying in the brown (pardo) and black (preto) census categories share similar positions of disadvantage in comparison to those of the white category (Lovell, 1999; Silva, 1985; Telles and Lim, 1998). Hence, informal systems of racial stratification appear to operate primarily, though not exclusively, along a white/non-white divide. For activists and some academics, maintaining a distinction between shades of non-white acts to hide the reality of that racial stratification system and to retard the formation of a negro identity for anti-racist mobilization (Bertulio, 1997). In addition, activist, academic and governmental use of the term negro may reflect the perceived need for greater precision in racial classification schemes for promoting and designing race-targeted public policy (Guimarães, 1999). ${ }^{6}$

\section{WHO USES EXTRA-OFFICIAL CATEGORIES?}

Given the long tradition of the white, brown (pardo), and black (preto) official categories, why would respondents in the survey context choose other categories as preferred descriptors when confronted with an open format question? The reasons may be hard to discern except in theory and through localized ethnographic studies, but understanding who chooses these categories, a relatively straightforward analysis, provides clues. Hence, we examine the social characteristics of persons that choose to identify in these categories rather than in the official ones. Specifically, how do education, age, sex, and local racial composition affect the choice of terms?

\section{Educational status}

High educational status, perhaps like social status generally, may allow darker individuals to whiten their racial classification (Harris, 1964; Wade, 1997), although Telles (2002) shows that reclassification in lighter census categories is not as great as previous literature suggests. However, whitening may also be manifested by choosing the moreno category, where its ambiguity may allow one to avoid being classified in a stigmatized category 
like black (preto). Therefore, a whitening hypothesis might suggests that persons with higher educational levels may move from black (preto) or even brown (pardo) to moreno, when given the choice and when it is not possible to identify as white. On the other hand, the term's popularity among the poor, as indicated by ethnographies (Harris et al., 1993; Pacheco, 1987), in contrast to its lack of popularity among leaders of the negro movement and university students (Hanchard, 1994; Turner, 1985), suggests that the term might be more common among the less educated.

Similarly, one could argue that the use of the term negro is either positively correlated with education or not. On the one hand, the negro movement in Brazil has long been characterized as a middle-class movement, resonating poorly with the mass of darker-skinned, presumably less-educated individuals (Bacelar, 1999). Similarly, other authors claim that racial affirmation as negro is especially strong among non-white collegeeducated professionals (Hanchard, 1994; Schwartzman, 1999; Turner, 1985). This may be due to their greater exposure to elite discourse, including that of the negro movement, or to a more critical awareness of racial discrimination, which increases with education (Sansone, 1995). While it may be clear that highly educated non-whites are increasingly using the negro term, a continued and perhaps growing use of it among the poor may offset the effects of education.

\section{Age}

Sansone's (1995) ethnographic research in Bahia revealed generational differences in the use of the terms negro and black (preto). While parents tended to use black (preto), their children ages 15-25 preferred negro. He attributes this in part to the growing popularity of transnational musical styles associated with black diaspora culture (such as reggae, funk and rap) among urban non-white youth (Sansone, 2003). Telles (2002) found that younger cohorts are especially likely to identify in black and white categories and disregard the brown (pardo) category. He suggests that this age effect reflects an increased socialization in black and white classification schemes. A rising use of the term negro might also come at the expense of a decreasing use of moreno. On the other hand, the literature also suggests a continuous popularity of the term moreno among youth (Guimarães, 1999; Sheriff, 2001), possibly due to its ability to downplay racial differences among peers.

\section{Sex}

By examining birth cohorts across censuses and adjusting for mortality, Wood (1991) found that the projected number of blacks (pretos) in 1980 (based on the 1950 census figures) was 38 percent less than the actual 
number registered in the 1980 census. He found that 41 percent of black (preta) females reclassified in lighter categories in comparison to 37 percent of black (preto) males, suggesting that the darker black (preto) category may be slightly less desirable for females than males. Telles (2002) addresses a related issue: gendered effects on interviewer classification of respondents. He finds that although women may choose to self-identify as black (preta), interviewers are especially unwilling to categorize women as such, suggesting a societal avoidance of the term that is greater when applied to women. In a study of racial bias and its effects on primary school children, Oliveira (1999) found that the term negra (the female version of negro) was the most negative of all racial terms in a test of self-esteem for both boys and girls. These studies may reveal a greater stigma to dark skin color in the case of women, suggesting that women may be more likely than men to choose morena and reject negra.

\section{Local racial composition}

We use the percentage white in urban areas, according to the 1991 Brazilian Census, as a proxy for local racial composition. Depending on the theoretical framing, one could expect that greater percentage white would increase monoracial affirmation or particularism and reduce ambiguity or have an opposite effect, i.e. reduce racial affirmation and increase ambiguity.

A first perspective rooted in classical sociology holds that in highly competitive areas class may supersede race, reducing the importance of racial distinctions (Fernandes, 1965). In the Brazilian case, areas of greater social and economic development are correlated with higher proportions of whites (Telles, 1994; Haller, 1982). ${ }^{7}$ To understand how extra-official classification may function in such areas, we recall that ethnographic studies reveal how the moreno term is used to downplay racial differences between individuals (Sansone, 1995) or to avoid oppositional positions within the color gradient (Reichmann, 1999). The ethnographic work attests to the opposite concerning the negro term. It represents the affirmation of racial difference (Sansone, 1995) and is associated with an increased possibility of mobilization along racial lines. Hence, we believe that classical theory would expect ambiguous, quasi-non-racial terms like moreno to become more popular and racially particularistic terms like negro to become less popular in more competitive or modern areas.

A second way to interpret this effect is through the extent that racial particularism is positively correlated with European immigration and inversely correlated with miscegenation (Guimarães, 1999; Telles, 2002). European immigration (1880 to 1930) was region specific and these regions have the largest proportions of whites (Skidmore, 1974). The incipient ethnic communities that emerged in these places furthered a particularist ethno-racial mentality (Fernandes, 1965; Guimarães, 1999). We expect that 
in this scenario, the African origin population would, like other ethnic groups, be more differentiated and attentive to race and ethnicity, and thus more likely to affirm a particularist identity represented by the term negro. Moreover, such places had less racial mixing because of the predominance of whites over non-whites (Telles, 2004) compared to regions where there was a greater balance of whites and non-whites. The increased levels of miscegenation in the places of lesser percent white would reinforce racial ambiguity (Telles, 2002). Based on these hypotheses, we expect a negative association between the percent white and the use of ambiguous terms such as moreno and a positive correlation between percent white and the ethnic affirmation term, negro.

\section{DATA}

We analyze data from a national face-to-face survey collected by the Data Folha Instituto de Pesquisas, the survey unit of the Folha de São Paulo, one of Brazil's major daily newspapers (Data Folha Instituto de Pesquisas, 1995). The survey was carried out in April 1995 and is officially called ' 300 Anos de Zumbi: Os Brasileiros e o Preconceito de Cor’ (300 Years of Zumbi: ${ }^{8}$ Brazilians and color prejudice). Data is based on a stratified national random sample of the urban population that is age 16 and over. Urban areas accounted for fully 76 percent of the Brazilian population in the 1991 Census (Telles and Lim, 1998). ${ }^{9}$ After selecting municipalities at random from within socioeconomic level, region and size strata, successive random samples are taken of neighborhoods, then streets and then individuals. The complete sample consists of 5014 persons sampled across 121 municipalities and roughly matches data from the 1991 and 2000 censuses on several important variables, including race, age and sex (Telles and Lim, 1998).

Data on respondent's color was collected in two ways. Towards the beginning of the questionnaire, interviewers asked respondents to selfidentify in an open-ended question. Subsequently, interviewers asked respondents to self-identify using the census format. The order in which these questions were prompted is important, because open-ended responses were not contaminated by responses to the closed format.

The entire survey sample, according to self-classification, is 53 percent white, 36 percent brown (pardo), 10 percent black (preto), 0.6 percent Asian and 1.1 percent Indian. Because of the small number of respondents in the Asian-descent and indigenous categories, these are not included in the statistical analysis. Hence, we limited the sample to persons who selfclassified as white, brown (pardo) or black (preto). 


\section{METHODS}

Our analysis begins with a cross-tabulation of self-classification in the open format by self-classification in the census format. ${ }^{10}$ We then employ multinomial logit regression to examine how select characteristics correlate with the use of non-census compared to census terms. The dependent variable is derived from the open-ended survey question 'What is your color.' By choosing the most frequent extra-official categories, we model the outcomes as moreno, moreno claro (a popular variation on moreno, literally light moreno), and negro. The omitted category comprised all of those choosing any of the three traditional census terms in the open-ended format: white, brown (pardo), or black (preto). This method permits an examination of propensities to classify in the extra-official categories compared the official census categories.

The independent variables that make up our preferred model are education, age, sex, color, and percent white. Education is represented by a variable with three levels of educational attainment: persons who have not completed primary school (low) (the omitted category), those who have completed primary but have not completed secondary school (medium) and those who have completed secondary school or more (high). Age is a continuous linear variable and sex is a dummy variable denoted by female. The independent color variable was formed according to self-classification in the census format: white, brown (pardo), and black (preto). Brown (pardo) was the omitted category. For local racial composition, we calculated the percent white of the urban area in which the respondent resided with information from the 1991 census and linked this information to the individual record. Although the sample included respondents from 122 municipalities, we constructed racial composition variables for 90 localities because single urban areas may contain several contiguous municipalities.

\section{PATTERNS IN THE USE OF EXTRA-OFFICIAL CATEGORIES}

\section{Bivariate analysis}

Table 1 reveals the frequency of extra-official categorization in Brazil. Interestingly, 94 percent of respondents self-classified in only six categories, including the three official categories and three extra-official terms. Fully 31.3 percent of the sample identifies as moreno, second only to the white classification at 42.0. The moreno claro category at 6.8 percent is the third most popular term followed by the official brown (pardo) classification (6.4 percent). Moreno claro is thus the second most common extra-official category. The fifth and sixth most popular categories are black (preto) at 4.7 
Table 1 Frequency of self-classification in open format, adult population in urban Brazil, 1995

\begin{tabular}{lrrr}
\hline & Frequency & Percentage & Cumulative percentage \\
\hline White & 1868 & 42.0 & 42.0 \\
Moreno & 1391 & 31.3 & 73.3 \\
Moreno claro & 303 & 6.8 & 80.1 \\
Brown (pardo) & 284 & 6.4 & 86.5 \\
Black (preto) & 208 & 4.7 & 91.2 \\
Negro & 131 & 2.9 & 94.1 \\
Claro & 76 & 1.7 & 95.8 \\
Mulato & 35 & 0.8 & 96.6 \\
Escuro & 31 & 0.7 & 97.3 \\
Moreno escuro & 21 & 0.5 & 97.8 \\
Canela & 7 & 0.2 & 98.0 \\
Moreno brown & 5 & 0.1 & 98.1 \\
(moreno pardo) & & & \\
Castanho & 4 & 0.1 & 98.2 \\
Mestiço & 80 & 0.1 & 98.3 \\
Others & 4447 & 1.8 & 100.1 \\
Total & & 100.1 & 100.1 \\
\hline
\end{tabular}

percent and negro at 2.9 percent. Finally, 5.9 percent self-identified in other categories, which include the relational, metaphoric and picturesque categories sometimes used to characterize Brazilian racial or color classification. Including these 'other' categories, 47 percent of the full sample chose extra-official categories when given the chance to do so.

Table 2 is a cross tabulation of self-classification in the open format and in the census format. It demonstrates the reclassification dynamics that take place when respondents are not limited to the official terms. For example, examining the column-percentaged figures, only 73.5 percent of persons self-classifying as white in the census-format choose white in the open format. Thus, almost 27 percent of self-classified whites of the census format reclassify in other categories when given the chance, with a significant number choosing the moreno $(13.3 \%)$ and moreno claro $(7.7 \%)$ classifications. More dramatically, though, is the reclassification dynamics of the brown (pardo) and black (preto) census categories. Only 18.8 percent of 
Table 2 Percent self-classifying in the census format by open format, adult population in urban Brazil, 1995

\begin{tabular}{lrrr}
\hline & \multicolumn{3}{c}{ Census format } \\
\cline { 2 - 4 } Open format & White & Brown & Black \\
\hline White & 73.5 & 3.5 & 0.3 \\
Brown (pardo) & 0.4 & 18.8 & 2.4 \\
Black (preto) & 0.1 & 2.1 & 29.7 \\
Moreno claro & 7.7 & 7.1 & 2.5 \\
Moreno & 13.3 & 60.6 & 37.9 \\
Negro & 0.0 & 1.7 & 18.0 \\
All others & 4.9 & 6.2 & 9.1 \\
Total & & 100.0 & 100.0 \\
$N$ & 100.0 & $(1421)$ & $(597)$ \\
\hline
\end{tabular}

self-classified browns (pardos) of the census format maintain this classification when given the opportunity to choose their color as they please. Most of them (60.6 percent) moved to the moreno category. For self-classified blacks (pretos) in the census format, only 29.7 percent reclassified as black (preto) in the open format while 37.9 percent self-classified again as moreno and 18.0 percent as negro.

The row percentages presented in Table 3 show the census category or color composition of the terms chosen as preferred descriptors in the open format. The moreno category is largely composed of browns (pardos) (at $60.1 \%$ ). Lesser numbers of census-classified whites and blacks (pretos) chose the moreno term in the open format, 23.7 percent and 16.2 percent respectively. Moreno claro is largely composed of self-classified whites of the census format (62.7\%), with fewer browns (pardos) choosing this option $(32.3 \%)$, and even fewer blacks (pretos) (5.0\%). The negro category is overwhelmingly composed of census-classified blacks (pretos) (at 81.7\%). Almost no whites chose this term, and only 17.6 percent of this category is comprised of self-classified browns (pardos) of the census format.

\section{Multivariate analysis}

Table 4 shows the overall effects of education, sex, age, color, and local racial composition. It reveals that education decreases the likelihood of identifying extra-officially in the moreno and moreno claro categories, while it 
Table 3 Percent self-classifying in open format by census format, adult population in urban Brazil, 1995

\begin{tabular}{|c|c|c|c|c|}
\hline \multirow[b]{2}{*}{ Open format } & \multicolumn{3}{|c|}{ Census format } & \multirow{2}{*}{$\begin{array}{l}\text { Total } \\
\text { (N) }\end{array}$} \\
\hline & White & Brown & Black & \\
\hline White & 97.3 & 2.6 & 0.1 & $\begin{array}{r}100.0 \\
(1868)\end{array}$ \\
\hline Brown (pardo) & 3.9 & 91.2 & 4.9 & $\begin{array}{l}100.0 \\
(284)\end{array}$ \\
\hline Black (preto) & 1.4 & 13.9 & 84.6 & $\begin{array}{l}100.0 \\
(208)\end{array}$ \\
\hline Moreno claro & 62.7 & 32.3 & 5.0 & $\begin{array}{l}100.0 \\
(303)\end{array}$ \\
\hline Moreno & 23.7 & 60.1 & 16.2 & $\begin{array}{r}100.0 \\
(1391)\end{array}$ \\
\hline Negro & 0.8 & 17.6 & 81.7 & $\begin{array}{c}100.0 \\
(131)\end{array}$ \\
\hline All others & 46.6 & 32.8 & 20.6 & $\begin{array}{c}100.0 \\
(262)\end{array}$ \\
\hline
\end{tabular}

increases the likelihood of identifying as negro. This suggests that the less educated, which roughly amounts to the poorest and largest population segment, prefers the traditional Brazilian system with its ambiguity and plurality of terms, while those that favor negro tend to be the highly educated.

Age is also statistically significant for both the moreno and moreno claro terms and the negro category. The negative correlations demonstrate that younger persons are especially likely to choose non-census categories. The age effect on the choice of negro is consistent with the reported growing popularity of the term in youth culture (e.g. Sansone, 2003). It is not fully clear why younger individuals also choose moreno and moreno claro, other than a possible growing sense among youth that the traditional census categories are become increasingly antiquated. However, if these associations of age with self-identification in extra-official categories prove to be period effects, then their popularity may continue to increase over time.

We found significant gender differences only in the preference for the negro label over official categories, showing that women were more likely than men to choose this label in an open-format question. This result contradicts the literature that reports that the negro term, traditionally 
Table 4 Multinomial logit regression coefficients predicting self-identification using open format as moreno, moreno claro, or negro compared to census categories, adult population, urban Brazil, 1995

\begin{tabular}{|c|c|c|c|}
\hline \multirow[b]{2}{*}{ Independent variables: } & \multicolumn{3}{|c|}{ Compared to census categories } \\
\hline & Moreno & Moreno claro & Negro \\
\hline \multicolumn{4}{|l|}{ Education } \\
\hline Medium education & $\begin{array}{c}-0.569^{* * *} \\
(.093)\end{array}$ & $\begin{array}{c}-0.240 \\
(0.139)\end{array}$ & $\begin{array}{l}0.552^{* *} \\
(.219)\end{array}$ \\
\hline High education & $\begin{array}{c}-1.104^{* * *} \\
(.167)\end{array}$ & $\begin{array}{c}-1.070^{* * *} \\
(0.276)\end{array}$ & $\begin{array}{c}0.604^{+} \\
(0.349)\end{array}$ \\
\hline Female & $\begin{array}{c}0.014 \\
(0.080)\end{array}$ & $\begin{array}{c}0.104 \\
(0.124)\end{array}$ & $\begin{array}{c}0.390^{*} \\
(0.200)\end{array}$ \\
\hline Age & $\begin{array}{c}-0.007^{* *} \\
(.003)\end{array}$ & $\begin{array}{c}-0.010^{*} \\
(0.004)\end{array}$ & $\begin{array}{l}-0.015^{*} \\
(0.008)\end{array}$ \\
\hline \multicolumn{4}{|c|}{ Self-classification in census format } \\
\hline White & $\begin{array}{c}-2.378^{* * *} \\
(0.089)\end{array}$ & $\begin{array}{c}-0.790^{* * *} \\
(0.141)\end{array}$ & ++ \\
\hline Black (preto) & $\begin{array}{c}-0.768^{* * *} \\
(0.162)\end{array}$ & $\begin{array}{c}-1.285^{* * *} \\
(0.293)\end{array}$ & $\begin{array}{l}4.064^{* * *} \\
(.248)\end{array}$ \\
\hline Percent white & $\begin{array}{c}-0.143^{* * *} \\
(0.017)\end{array}$ & $\begin{array}{c}-0.126^{* * *} \\
(0.026)\end{array}$ & $\begin{array}{c}0.050 \\
(0.044)\end{array}$ \\
\hline Intercept & $\begin{array}{l}2.132^{* * *} \\
(0.164)\end{array}$ & $\begin{array}{c}-0.160 \\
(0.254)\end{array}$ & $\begin{array}{c}-4.849^{* * *} \\
(0.479)\end{array}$ \\
\hline$N$ & 4179 & & \\
\hline Likelihood Ratio $\mathrm{Chi}^{2}$ & 1642.13 & & \\
\hline
\end{tabular}

$+p<.10 * p<.05 * * p<.01 * * * p<.001$

( ) indicates standard errors

++ Whites rarely classified as negro

Note: For the dependent variable, the omitted category is self-classification as white, brown (pardo) or black (preto). For the independent variables, omitted categories are low for education and brown (pardo) for racial self-classification. Age and percent white are continuous variables.

viewed as stigmatized for all Brazilians, is especially offensive to women (Oliveira, 1999) and shows instead that it may now be preferable to the census black (preto) label. This suggests a significant shift in the meaning of this term, perhaps towards a collective negro affirmation and pride. 
Both local racial composition and where a person is located on the color continuum also affect whether persons choose extra-official terms. Percent white significantly affects identification as moreno and moreno claro in a negative direction, and color has significant effects on all the extra-official categories at some point along the color continuum. To more clearly understand the effects of color and percent white and to gauge the strength of the other effects, Table 5 presents relative risks (odds ratios) to classify as moreno, moreno claro, or negro categories compared to census classifications for select characteristics.

The first row of the first column shows that the odds that respondents with a medium education will choose moreno over the official terms are only about 57 percent, as great as the odds of those with a low education, when all other variables are held constant. The cell immediately underneath demonstrates that the odds that respondents with a high education will choose moreno are 33 percent as great as the odds of those with a low education. Regarding the choice of negro, the odds that respondents with a high level of education will choose negro over the official terms are 1.8 times greater compared to those with a low level of education. These results support the perspective that racial affirmation and the choice of the negro term resonate most clearly with persons of higher education (Bacelar, 1999; Hanchard, 1994; Turner, 1985). In addition, at least in terms of classification as negro and moreno, our results do not suggest a whitening thesis in which persons with higher status positions 'lighten' their racial classification (Degler, 1986[1971]; Skidmore, 1974; Wade, 1997); rather, they suggest a new trend: high status in the way of education influences positively the choice of the negro, while low status implies greater use moreno.

In terms of age, the odds of choosing moreno relative to the census terms are 1.3 times greater for a 20 -year-old respondent compared to a 60 year-old. The odds of choosing negro relative to official categorization are 1.8 times greater based on those same age differences. These results support previous findings that the negro term has gained in popularity among young persons (Sansone, 1993; Schwartzman, 1999). In addition, it appears that the moreno term is also especially attractive to younger individuals.

Concerning our color categories, we begin in column one and their effects on the choice of moreno over the census terms. For example, the odds that respondents in the white category compared to the brown (pardo) category will choose moreno are only about 9 percent as great as the odds that they will choose the official terms. The odds that respondents in the black (preto) category compared to the brown (pardo) will choose moreno are about 46 percent as great as the odds that they will choose the official terms. Hence, although moreno is often believed to be applicable to nearly the entire color spectrum and therefore to represent a universalist tendency, individuals that self-identify as white or as black (preto) are much less likely than browns (pardos) to chose moreno (and moreno claro) over the official 
Table 5 Relative risk of self-identifying in open-ended color question as moreno, moreno claro, negro compared to census categories for select comparisons of characteristics, adult population, urban Brazil, 1995

Compared to census categories

\begin{tabular}{|c|c|c|c|}
\hline Categories compared & Moreno & Moreno claro & Negro \\
\hline \multicolumn{4}{|l|}{ Education } \\
\hline Medium vs. Low & 0.57 & 0.79 & 1.74 \\
\hline High vs. Low & 0.33 & 0.34 & 1.83 \\
\hline Female vs. Male & 0.99 & 1.11 & 1.48 \\
\hline \multicolumn{4}{|l|}{ Age } \\
\hline 20 vs. 40 -year-olds & 1.15 & 1.22 & 1.35 \\
\hline 20 vs. 60 -year-olds & 1.32 & 1.49 & 1.83 \\
\hline \multicolumn{4}{|l|}{ Interviewer/self-classification } \\
\hline \multicolumn{4}{|l|}{ In census format* } \\
\hline White & 0.09 & 0.45 & + \\
\hline Black (preto) & 0.46 & 0.28 & 58.21 \\
\hline \multicolumn{4}{|l|}{ Percent white } \\
\hline $\begin{array}{l}25 \% \text { White (e.g. Bahia) vs. } 55 \% \\
\text { white (e.g. Rio de Janeiro) }\end{array}$ & 72.35 & 43.25 & 0.22 \\
\hline $\begin{array}{l}25 \% \text { White (e.g. Bahia) vs. } 70 \% \\
\text { white (e.g. São Paulo) }\end{array}$ & 615.38 & 284.39 & 0.12 \\
\hline
\end{tabular}

* Brown (pardo) is the reference category

+ Whites never classified as negro

census terms. These findings suggest that there is some limit to the inclusive nature of this term as concerns both the lighter and the darker end of the color spectrum (see Wade, 1997).

Regarding the choice of negro over the census terms (third column), the darkest end of the color spectrum heavily favors this term compared to the brown (pardo) category - the odds are 58 times greater that an individual of the black (preto) category compared to the brown (pardo) category will choose negro over the official terms. This tendency also suggests limits to the inclusiveness of racially ambiguous terms like moreno and moreno claro, perhaps not considered real options for individuals of the darkest end of the color spectrum (Wade, 1997). In addition, it indicates that instead of 
being understood as an umbrella term for all non-whites, the negro category carries meaning closer to that of the black (preto) census term.

Turning to the effect of percent white on whether an individual prefers extra-official categories to the official census terms, we find a dramatic influence in the cases of moreno and moreno claro. In places such as Bahia, where whites make up only 25 percent of the local population, the odds that individuals will prefer moreno over the census terms are about 72 times greater than in places, like Rio de Janeiro, that are 55 percent white. Comparing a place like Bahia to São Paulo that is 70 percent white, the odds are 615 times greater that an individual will choose moreno over official categories. These results contradict the expected positive effect of competition on racial ambiguity (Fernandes, 1965), i.e. as percent white decreases, racially ambiguous terms become more prevalent. The results lend support to the perspective on European immigration that holds for its negative effect on racial ambiguity (Guimarães, 1999). Individuals residing in those areas receiving the bulk of white European immigrants (higher percent white) are less likely to opt for the racially ambiguous terms like moreno and moreno claro.

Due to the complexity of the odds ratio interpretation, a graphic illustration best reveals the overall regression results. Figure 1 presents summaries of our results using 'odds ratio plot[s]' (Long, 1997). In the two panels of this figure, each row represents an independent variable's relationship to the outcome variable if it is a continuous variable. If an independent variable is categorical, each row presents one value of the independent variables' relationship to the dependent variable compared to a reference category. The plotted letters represent each category of the dependent variable - 'C' (census categories comparison group), ' $M$ ' (moreno), 'L' (moreno claro), and 'N' (negro). The horizontal scale at the top of each figure marks the factor change relative to ' $\mathrm{C}$ ', and at the bottom, the marks plot the logit coefficient relative to ' $C$ '. Categories located to the right of the ' $C$ ' reference category show that the independent variable represented by the row (or the value of the independent variable if categorical) is positively associated with the choice of that extra-official category over the census terms grouping. The opposite is true for those to the left of the comparison ' $C$ ' grouping.

The first two rows of Panel 1, for example, show that education (medium and high compared to low, respectively) has a positive effect on the choice of negro over the census terms, while education is negatively associated with the choice of moreno and moreno claro compared to the census terms. The third row shows that women are significantly more likely than men to choose negro over the census terms. Regarding color, row 4 reveals that whites are significantly less likely than browns (pardos) to choose moreno and moreno claro over the census terms. Row 5 shows the popularity of the negro term for blacks (pretos) in relation to browns (pardos), and that 
Panel 1

Effects of education, sex, and color (categorical variables)

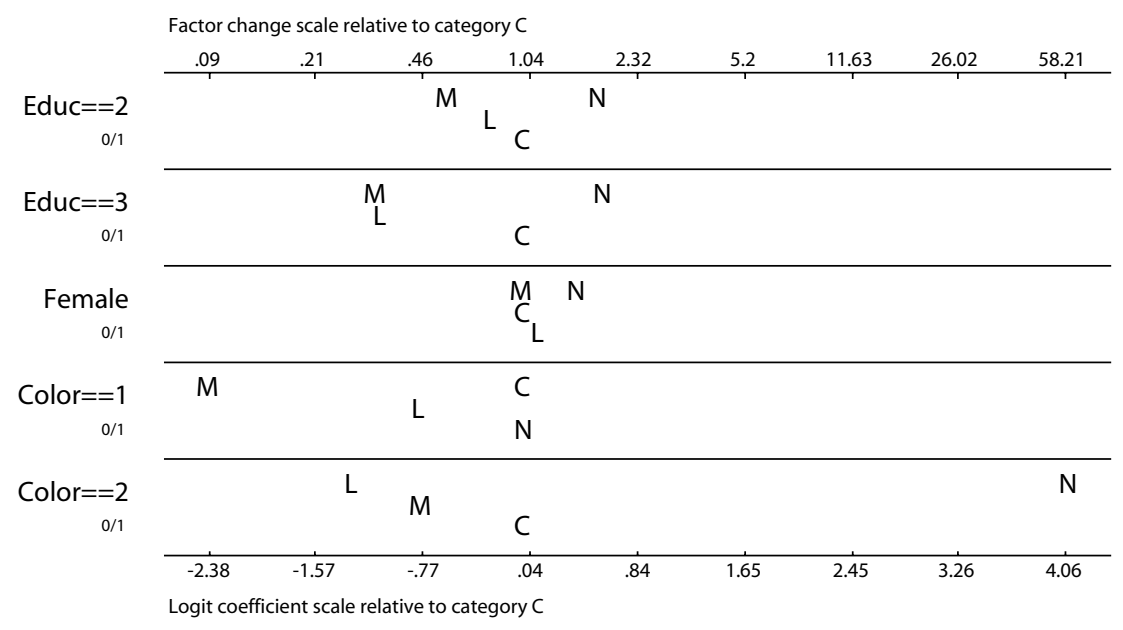

Panel 2

Effects of percent white and age (continuous variables)

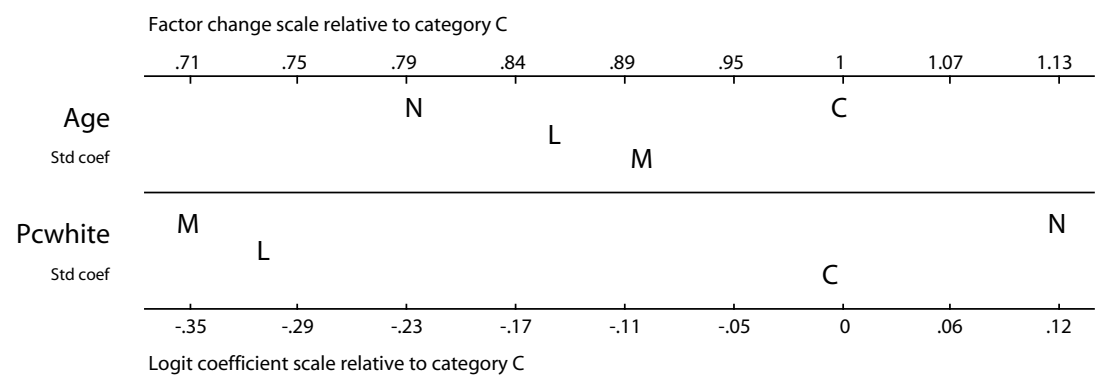

Figure 1 Odds ratio plots predicting self-identification as moreno (M), moreno claro $(\mathrm{L})$, and negro $(\mathrm{N})$, compared to census categories $(\mathrm{C})$ for select independent variables, adult population in urban Brazil, 1995

blacks (pretos) are significantly less likely than browns (pardos) to choose moreno and moreno claro. In Panel 2, the first row presents the negative relationship of age to the choice of any of the extra-official terms over the census categories. Finally, the second row reveals that the choice of the moreno and moreno claro terms decreases significantly as percent white increases. The increased likelihood of the choice of negro over the census terms is not significant. 


\section{SUMMARY AND DISCUSSION}

We began this analysis noting the growing tension in census racial classification debates between the right to self-identify and the necessity to monitor and redress racial discrimination. These two concerns are central to census debates in Brazil regarding the proposed inclusion of the multiracial moreno term versus that of the collective negro category. What does it mean to be moreno as opposed to negro? What factors influence the choice of these two terms? In this section, we summarize our findings for the Brazilian census debate and discuss how shifting racial schemes in Brazil might affect the monitoring/redressing of racial inequality, as well as the possible effects of census naming on racial demographics.

\section{Multiracial identification}

According to ethnographic accounts, self-identification as moreno suggests the embracing of racial mixture (Sansone, 2003; Sheriff, 2001). The moreno label is believed to represent a national inclusive identity; in part, to selfidentify as moreno is to embrace 'Brazilianness'. This perspective may exemplify Gilberto Freyre's projection of the creation of a metarace in Brazil (Nobles, 2000) - in effect, the birth of a new people not reflected in white versus negro categorization schemes (Freyre,1979). Our results show that nearly 40 percent of Brazilians in our survey chose this label when combined with its variation, moreno claro, attesting to its high level of saliency in the population. The popularity of this term is impressive, especially in the Northeast (region of lowest percent white), considering that it has never been a part of Brazilian censuses since their initiation in 1872.

Self-identification as moreno is preferred by younger individuals in Brazil as shown through the negative effect of age on the choice of the moreno category over official census terms. ${ }^{11}$ A possible explanation for this effect is that in sectors of youth culture, traditional ambiguity may be embraced to downplay racial differences among peers. Brazilians may come to place more emphasis on racial difference later on in life as they enter the job market where racial distinctions take on more importance (Sansone, 1995). If preferences among younger individuals for moreno in Brazil are actually period effects as opposed to age effects, then the popularity of this multiracial identifier may be expected to increase.

Strikingly, preference for the moreno term in Brazil is especially salient among the lower education stratum, which comprises the majority population of the country. Here, social class may be the more salient boundary (Bailey, 2002, 2004). Supporting this possibility, researchers claim that racism in Brazil increases with social mobility (Andrews, 1991; Guimarães, 2001), making racial distinctions less important to relationships among the 
disadvantaged. A preference for the ambiguous moreno term that downplays racial difference may allow greater class solidarity. Contrary to the age effect, however, the negative correlation with education suggests that its use may decrease as the population's education level increases. ${ }^{12}$

Geography also influences the preference for multiracialism in Brazil. The multiracial moreno term is very popular in the areas of the lowest percent white. Those areas, like the northeastern state of Bahia, are also the poorest in Brazil.

\section{The collective black category}

Some researchers and negro activists argue that the choice of negro reflects racial affirmation in Brazil and a consciousness of the historical plight of Brazilians of some African descent. Hence, they emphasize the importance of this term for mobilization against historic and contemporary racial discrimination (Bertulio, 1997; Guimarães, 1999). Although used much less than moreno, the 2.9 percent of the population that chose negro in 1995 represents a six-fold increase from the 0.5 percent that chose the term in the 1976 national survey, suggesting a strongly growing base of support for this term. As with the moreno category, the choice of negro is notable because it has never been an official census category.

Brazilians who prefer to self-classify as negro tend to be young, educated, and phenotypically located at the darkest end of the continuum. The age effect may be due to the changing meaning of this term in urban youth culture - from stigmatized and antiquated to a modern identity. This trend reflects in part the influence on Brazilian youth culture of contemporary black culture in the USA, portrayed through the popularity of US music, film and television, and commercial products (Sansone, 2003).

The positive relation between education and the choice of negro over traditional Brazilian census categories suggests that higher education may lead to a greater awareness of the systems of social stratification in Brazil. The understanding that these systems fall along white versus non-white lines may lead individuals of higher educational attainment to reflect that consciousness in their preferences for a collective black self-identification.

Brazilian negros are overwhelming made up of those who self-identify as black (preto) in the official census format. This finding suggests the correlation between darker skin color and the collective black in Brazil. In addition, it suggests that there are some limits to the presumed inclusive nature of the moreno label.

That high-status and darker-skinned persons are especially likely to choose negro today in Brazil is an important change from the tradition captured by anthropologists in the 1950s and 1960s that 'money whitens' (see also Telles, 2002). Usage of negro is thus likely to continue growing if 
levels of educational attainment continue to increase for the general population and the age effect does not merely signal a passing fad.

\section{The effect of classification schemes on civil rights}

Commenting on Harris and his colleagues' 1993 study, Telles (1995) argues against the inclusion of the moreno term as an official race category in Brazil (see also Silva, 1996). He contends that because the moreno category includes persons that are socially classified as white, the use of moreno rather than brown (pardo) would preclude any reasonable assessment of social inequalities by race or color in Brazil (see Schwartzman, 1999). ${ }^{13}$ Our results support this view that certain flexibility as regards phenotype characterizes the moreno category. This is demonstrated by the reclassification dynamics in which 13.3 percent of self-classified whites prefer moreno when allowed a choice. Hence, its use as a census term might well blur the boundary that researchers argue to be the decisive cleavage in Brazil in terms of socioeconomic disadvantage: between whites and non-whites (Lovell, 1999; Oliveira et al., 1985).

Would the inclusion of the negro term in the Brazilian census as an umbrella non-white category help in monitoring racial discrimination? If forced to choose between white and negro, many browns (pardos) (and even some blacks (pretos)) may choose white, for, as our results show, the negro term is decidedly non-salient among non-whites. This dynamic could result in a counting that is overwhelmingly white (Nobles, 2000) and that also blurs the white/non-white cleavage. Hence, forced classification in a non-salient collective black term could backfire.

Even though not an official census term, researchers have used the negro category for over 30 years to document racial inequality (e.g. Oliveira et al., 1985). They have done so through the reallocation of browns (pardos) and blacks (pretos) into a statistical category negro that does not represent a subjectively defined racial group. Hence, the current three-category system appears to permit the study of the crucial white versus non-white cleavage (e.g. Lovell, 1999), leading Nobles (2002) to claim that, 'Multiracialism in Brazil does not mean that discrimination cannot be documented or proved' (p. 301), albeit by way of reallocation. ${ }^{14}$

Beyond proving discrimination, multiracialism may be particularly problematic for the administration of affirmative action policies. In fact, Skerry (2002), commenting on the use of race-targeted policies in the USA, claims that 'multiracialism may well be the silver bullet that finishes off the affirmative action regime' (p. 338). The fluidity it introduces contradicts the assumptions on which race-targeted strategies depend, 'that racial boundaries are fixed and unambiguous' (Snipp, 1997: 674).

Early experiences in Brazil illustrate this multiracialism problem. At the State University of Rio de Janeiro, the racial quota categories for university 
entrance were changed from 'brown (pardo) and negro' in 2001 to only 'negro' in 2003 (Bailey, 2004; Telles, 2004). This switch was a response to apparent racial fraud (i.e. whites self-identifying as browns (pardos)) for quota inclusion) (Merola, 2003). The expressed logic for this change was that although a white individual might try to pass for brown (pardo) or multiracial, it is unlikely that he or she would go so far as to claim to be negro/a (Merola, 2003). Hence, if boundaries of the official brown (pardo) term are problematic, the even greater ambiguity that surrounds moreno (the preferred self-identification term for 13.3 percent of whites in our survey) might prove a daunting obstacle.

In another case, the newest legislation from the federal University of Brasilia also reflects a move towards monoracial categories for racetargeted policy. The quota legislation in that case reads: 'To compete for the openings reserved through the quota system for negros, a candidate should: be of brown (pardo) or black (preto) color, declare one's self negro, and specifically opt for the quota system for negros' (Universidade de Brasilia, 2004; Telles 2004). This revised legislation represents a novel 'selfreallocation' system into a collective black category. Hence, according to these early experiences with affirmative action in Brazil, universities appear to be turning to the negro category to more efficiently administer racetargeted strategies.

\section{The effects of census naming}

The reclassification dynamics in Brazil suggest that, contrary to the literature on the importance of state naming for the creation of racial and ethnic group identification, the use of the brown (pardo) and black (preto) terms in the decennial censuses for the last 150 years has not resulted in the establishment of these terms as preferred categories for self-identification. For example, the official term for brown (pardo) is decidedly unpopular (Harris et al., 1993; Schwartzman, 1999), although like moreno, it represents racial mixture (Nobles, 2002). Hence, the influence of the state on preferences for self-identification is not straightforward, as much of the literature suggests. One conditioning variable may be a state's use of these categories for the distribution of rights and resources, as historically practiced in the USA. In Brazil, there has never been de jure racial discrimination in postabolition years and, until recently, affirmative action programs were unknown. Hence, if the census categories in Brazil begin to be used for racetargeted public policy, then their saliency and acceptance might increase.

Those proposing the adoption of the negro term do so with the hope that its institutionalization would help to build a unified non-white identity (Guimarães, 1999; Nobles, 2000). In fact, sociologist Guimarães (1999) identifies identity construction as 'one of the goals of affirmative action policies' (p. 192). The adoption of the negro category and its connection to 
the distribution of resources, as is the case in quota legislation at several Brazilian universities, could give some life to that goal. In this sense, Guimarães (1999) writes, 'the legislator will be helping to create, through legislation, the community [of negros] over which it seeks to legislate' (p. 191).

The effect of including the moreno term in the census would probably result in a very large moreno population and, if used in conjunction with negro, a very small monoracial negro population. ${ }^{15}$ In fact, if Brazilians were forced to choose between white, moreno, and negro, it is very likely that the majority white character of Brazil would cease to exist (Harris et al., 1993; Nobles, 2000). This effect would no doubt be exaggerated if, in addition, the moreno category were also used for affirmative action policies.

\section{CONCLUSION}

In sum, although the current terms employed by the Brazilian census are not ideal, the proposed alternatives may be less so. On the one hand, the inclusion of the multiracial moreno term may respect 'the right to selfidentification' (Harris et al., 1995), but it could seriously challenge the ability of the state to 'approximate the extent of racial inequalities and the effects of racist practices' (Telles, 1995: 1611). On the other hand, the inclusion of negro, although proposed as the term that most clearly reflects stratification dynamics in Brazil (a white vs non-white or negro divide) (Guimarães, 1999), could also confound estimates of racial disadvantage by pushing many non-whites into the white category. In addition, it is not a preferred term for self-identification among non-whites, who have not shown a propensity towards a collective black identity (Nobles, 2000).

In both Brazil and the USA, the tension between multiracial and monoracial categories will only intensify. The reasons are clear: racial categories are not based in biology; they are subjective and political in nature, and therefore in flux across time and through shifting political projects. As Snipp (2002) has concluded:

The stability and invariance of benchmark racial classifications is no longer a realistic assumption. The challenge to social scientists, and anyone else with a serious interest in race and ethnicity, will be to understand the sources of this variability. Absent this knowledge, any effort to comprehend the racial and ethnic composition of American society is likely to be an exercise in futility. (p. 213)

It is clear that the same applies to the study of racial dynamics in Brazil. However, the subjective and fluid nature of racial and ethnic labels should not undermine the continuing struggle against objective race-based 
discrimination. In the end, the existence of historic and contemporary racial discrimination is perhaps the only justification for state counting by race in the first place.

\section{Acknowledgements}

The research was supported by NSF Grant SBR-9710366, and Stan Bailey thanks the Andrew W. Mellon Foundation Fellowship for Sociology of Latin American, which supported him during the research.

\section{Notes}

1 'White,' 'brown,' and 'black' are approximate translations of the Brazilian census categories branco, pardo, and preto, respectively.

2 No censuses were conducted in 1910 and 1930.

3 Some of these exchanges appeared as editorials in the Jornal do Brasil in 1999 but most went unnoticed. The second author of this article, as a Ford Foundation Program Officer in Brazil at the time, followed the discussions with several of the participants. The use of moreno as a category was brought up, but only received secondary attention compared to whether negro or afrodescendente (an equivalent for negro) should be used. Despite the directives of the National Plan for Human Rights that advised the IBGE to use the negro category, it decided to retain the 1991 categories, largely because extensive pre-testing showed greater popular understanding and precision of the traditional census categories (Schwartzman, 1999).

4 Both moreno and the census term pardo roughly translate as brown, although with different connotations. To avoid confusion, we refer to the moreno term only in Portuguese. In addition, the census brown term will be accompanied by the original Portuguese (pardo).

5 To avoid confusion, we refer to the term negro only in Portuguese. In addition, the census black term will be accompanied by the original Portuguese (preto).

6 Possibly further supporting an argument for collapsing of non-white categories for analytic purposes, Telles (2002) finds that ambiguity in Brazilian racial classification is especially high between the white and brown (pardo) categories compared to between black (preto) and brown (pardo).

7 Telles (1994) shows a zero-order correlation between the percent of the labor force employed in manufacturing with percent white of .532 among the 40 largest urban areas.

8 The title refers to 300 years since the birth in 1695 of Zumbi, the leader of a runaway slave colony (Quilombo de Palmares), which lasted nearly 100 years.

9 In his study of racial attitudes in the state of Rio de Janeiro, Bailey (2004) found no difference between the attitudes of rural and urban individuals.

10 For all of the statistical analyses we employ sampling weights ranging from .4 to 1.6.

11 Farley (2002a, 2002b) notes the negative effect of age on the choice of more than one race in the USA.

12 Farley (2002b) reports a significant education effect on self-classification in more 
than one category in the 2000 US Census, but in the opposite direction. Multiracial individuals have higher levels of education on average than monoracials.

13 In contrast, Harris et al. (1995) claim the opposite, that moreno is less ambiguous than the official census brown (pardo) term.

14 See Goldstein and Morning (2002) on the newly established use of reallocation techniques in the USA with the 2000 Census.

15 In the USA, the fear of a significant out flux of monoracial blacks to multiracialism was what prompted in large part the opposition of leaders of the black community to include a multiracial option in the 2000 US Census (Spencer, 1999).

\section{References}

Andrews, G.R. (1991) Blacks and Whites in São Paulo, Brazil, 1888-1988. Madison,WI: The University of Wisconsin Press.

Bacelar, J. (1999) 'Blacks in Salvador: Racial Paths', in L. Crook and R. Johnson (eds) Black Brazil, pp. 85-101. Los Angeles: UCLA Latin American Center Publications.

Bailey, S. (2002) 'The Race Construct and Public Opinion: Understanding Brazilian Beliefs About Racial Inequality and Their Determinants', American Journal of Sociology 108(2): 406-39.

Bailey, S. (2004) 'Group Dominance and the Myth of Racial Democracy: Antiracism Attitudes in Brazil', American Sociological Review 69: 725-44.

Barcelos, L. (1999) 'Struggling in Paradise: Racial Mobilization and the Contemporary Black Movement in Brazil', in R. Reichmann (ed.) From Indifference to Inequality: Race in Contemporary Brazil, pp. 155-66. University Park, PA: Pennsylvania State University Press.

Bertulio, D. (1997) 'Enfrentamento do Racismo em um Projeto Democrático' (Challenging Racism in a Democratic Project), in J. Souza (ed.) Multiculturalismo e Racismo: Uma Comparação Brasil-Estados Unidos (Multiculturalism and Racism: A Brazil-United States comparison), pp. 189-208. Brasilia: Paralelo 15.

Brasil (1996) Programa Nacional de Direitos Humanos (National Program of Human Rights). Brasilia: Ministério da Justiça, Secretaria Nacional de Direitos Humanos, Imprensa Nacional.

Byrne, B., M. Harris, J. Consort and J. Lang (1995) 'What's in a Name? The Consequences of Violating Brazilian Emic Color-Race Categories in Estimates of Social Well-Being', Journal of Anthropological Research 51: 389-97.

Daniels, G. (2002) More than Black? Multiracial Identity and the New Racial Order. Philadelphia, PA: Temple University Press.

Data Folha Instituto de Pesquisas (1995) '300 Anos de Zumbi: Os Brasileiros e o Preconceito de Cor' (300 Years of Zumbi: Brazilians and Color Prejudice), São Paulo, Brazil.

Degler, C. (1986[1971]) Neither Black nor White: Slavery and Race Relations in Brazil and the United States. Madison, WI: University of Wisconsin.

Farley, R. (2002a) 'Racial Identities in 2000: The Response to the Multiple-Race Response Option', in J. Perlmann and M. Waters (eds) The New Race Question, pp. 33-61. New York: Russell Sage Foundation. 
Farley, R. (2002b) 'Race Reporting in the Census of 2000: How Do Multiracial Groups Compare to Monoracial Groups on Key Characteristics?', Working Paper No 02-516, Population Studies Center, Ann Arbor, Michigan.

Fernandes, F. (1965) A Integração do Negro na Sociedade de Classes (The Integration of the Negro in the Society of Classes). São Paulo: Dominus Editora. Fernandes.

Freyre, G. (1946) The Masters and the Slaves. New York: Alfred A. Knopf.

Freyre, G. (1979) 'Brasileiro - sua cor?' (Brazilian - your color?), Folha de São Paulo, 5 December: 3.

Goldstein, J. and A. Morning (2002) 'Back in the Box: The Dilemma of Using Multiple-Race Data for Single-Race Laws', in J. Perlmann and M. Waters (eds) The New Race Question, pp. 119-36. New York: Russell Sage Foundation.

Guimarães A. (1999) Racismo e Anti-Racismo no Brasil (Racism and Anti-Racism in Brazil). São Paulo: Editora 34.

Guimarães, A. (2001) 'The Misadventures of Nonracialism in Brazil', in C. Hamilton, L. Huntley, N. Alexander, A. Guimarães, and W. James (eds) Beyond Racism: Race and Inequality in Brazil, South Africa, and the United States, pp. 157-85. Boulder, CO: Lynne Rienner Publishers.

Haller, A. (1982) 'A Socio-Economic Regionalization of Brazil', Geographic Review 72: 450-64.

Hanchard, M. (1994) Orpheus and Power: The Movimento Negro of Rio de Janeiro and São Paulo, Brazil, 1945-1988. Princeton, NJ: Princeton University Press.

Harris, D. and J. Sim (2002) 'Who is Multiracial? Assessing the Complexity of Lived Race', American Sociological Review 67: 614-27.

Harris, M. (1964) Patterns of Race in the Americas. New York: Walker.

Harris, M., J. Consorte, J. Lang and B. Byrne (1993) 'Who are the Whites? Imposed Census Categories and the Racial Demography of Brazil', Social Forces 72: 451-62.

Harris, M., J. Consorte, J. Lang and B. Byrne (1995) 'A Reply to Telles', Social Forces 73: $1613-14$.

Harrison, R. (2002) 'Inadequacies of Multiple-Response Race Data in the Federal Statistical System', in J. Perlmann and M. Waters (eds) The New Race Question, pp. 137-60. New York: Russell Sage Foundation.

Hasenbalg, C. (1985) 'Race and Socioeconomic Inequalities in Brazil', in P.M. Fontain (ed.) Race, Class and Power in Brazil, pp. 25-41. Los Angeles: Center for Afro American Studies, UCLA.

Hirschman, C., R. Alba and R. Farley (2000) 'The Meaning and Measurement of Race in the US Census: Glimpses into the Future', Demography 37(3): 381-93.

Hutchinson, H. (1957) Village and Plantation Life in Northeastern Brazil. Seattle, WA: University of Washington.

Jacobson, M. (2002) 'History, Historicity, and the Census Count by Race', in J. Perlmann and M. Waters (eds) The New Race Question, pp. 259-62. New York: Russell Sage Foundation.

Levine, R. (1979) Historical Dictionary of Brazil. Metuchen, NJ: Scarecrow Press.

Long, S. (1997) Regression Models for Categorical and Limited Dependent Variables. Thousand Oaks, CA: Sage Publications.

Lovell, P. (1999) 'Development and the Persistence of Racial Inequality in Brazil: 1950-1991', Journal of Developing Areas 33: 395-418. 
Merola, E. (2003) 'Não Haverá Distorções' (There will be no distortions), O Globo 9 September: 3 .

Nobles, M. (2000) Shades of Citizenship: Race and the Census in Modern Politics. Stanford, CA: Stanford University Press.

Nobles, M. (2002) 'Lessons from Brazil: The Ideational and Political Dimensions of Multiraciality', in J. Perlmann and M. Waters (eds) The New Race Question, pp. 300-17. New York: Russell Sage Foundation.

Oliveira, I. (1999) Desigualdades Raciais: Construções da Infância e da Juventude (Racial inequalities: Constructions of Infancy and Youth). Niteroi, Brasil: Intertexto.

Oliveira, L., R. Porcaro and T. Araújo (1985) O Lugar do Negro na Força de Trabalho (The Place of the Negro in the Work Force). Rio de Janeiro: IBGE.

Pacheco, M. (1987) 'A Questão da Cor nas Relações de um Grupo de Baixa Renda' (The Color Question among a Low-Salaried Group), Estudos Afro-Asiaticos 14: 85-97.

Perlmann, J. and M. Waters (2002) 'Introduction', in J. Perlmann and M. Waters (eds) The New Race Question, pp. 1-30. New York: Russell Sage Foundation.

Persily, N. (2002) 'The Legal Implications of a Multiracial Census', in J. Perlmann and M. Waters (eds) The New Race Question, pp. 161-86. New York: Russell Sage Foundation.

Reichmann, R. (1999) 'Introduction', in R. Reichmann (ed.) From Indifference to Inequality: Race in Contemporary Brazil, pp. 1-35. University Park, PA: The Pennsylvania State University Press.

Sansone, L. (1993) 'Pai Preto, Filho Negro: Trabalho, Cor e Diferenças de Geração' (Black Father, Negro Son: Work, Color and Generational Differences), Estudos Afro-Asiáticos 25: 73-98.

Sansone, L. (1995) 'O Local e o Global na Afro-Bahia Contemporânea' (The Local and the Global in Contemporary Afro-Bahia), Revista Brasileira de Ciencias Sociais 29: 65-84.

Sansone, L. (2003) Blackness without Ethnicity: Constructing Race in Brazil. New York: Palgrave Macmillan.

Schwartzman, S. (1999) 'Fora de Foco: Diversidade e Identidades Étnicas no Brasil' (Out of Focus: Diversity and Ethnic Identities in Brazil), Novos Estudos 55: 83-96.

Sheriff, R. (2001) Dreaming Equality: Color, Race, and Racism in Urban Brazil. New Brunswick, NJ: Rutgers University Press.

Silva, N. (1985) 'Updating the Cost of Not Being White in Brazil', in P.M. Fontain (ed.) Race, Class and Power in Brazil, pp. 42-55. Los Angeles: Center for Afro American Studies, UCLA.

Silva, N. (1996) 'Morenidade: Modo de Usar' (Morenidade: Term usage), Estudos Afro-Asiáticos 30: 79-95.

Skerry, P. (2002) 'Multiracialism and the Administrative State', in J. Perlmann and M. Waters (eds) The New Race Question, pp. 327-39. New York: Russell Sage Foundation.

Skidmore, T. (1974) Black into White: Race and Nationality in Brazilian Thought. New York: Oxford University Press.

Snipp, C. (1997) 'Some Observations about Racial Boundaries and the Experiences of American Indians', Ethnic and Racial Studies 20(4): 667-89. 
Snipp, C. (2002) 'American Indians: Clues to the Future of Other Racial Groups', in J. Perlmann and M. Waters (eds) The New Race Question, pp. 189-215. New York: Russell Sage Foundation.

Spencer, R. (1999) Spurious Issues: Race and Multiracial Identity Politics in the United States. Boulder, CO: Westview Press.

Starr, P. (1987) 'The Sociology of Official Statistics', in W. Alonso and P. Starr (eds) The Politics of Numbers, pp. 7-57. New York: Russell Sage Foundation.

Telles, E. (1994) 'Industrialization and Occupational Racial Inequality in Employment: The Brazilian Example', American Sociological Review 59: 46-63.

Telles, E. (1995) 'Who are the Morenos?', Social Forces 73(4): 1609-11.

Telles, E. (2002) 'Racial Ambiguity among the Brazilian Population', Ethnic and Racial Studies 25(3): 415-41.

Telles, E. (2004) Race in Another America: The Significance of Skin Color in Brazil. Princeton, NJ: Princeton University Press.

Telles, E. and N. Lim (1998) 'Does it Matter who Answers the Race Question? Racial Classification and Income Inequality in Brazil', Demography 35: 465-74.

Turner, J. (1985) 'Brown to Black: Changing Racial Attitudes of Afro-Brazilian University Students', in P. Fontaine (ed.) Race, Class, and Power in Brazil, pp. 73-94. Los Angeles: Center for Afro-American Studies.

Universidade de Brasilia (2004) 'Edital de Apertura' [http://www.cespe.unb.br/ vestibular/arquivos/2004-2/ED_2004_2_VEST_2004_3_ABT_I.PDF].

Wade, P. (1997) Race and Ethnicity in Latin America. London: Pluto Press.

Wagley, C. (1963) Race and Class in Rural Brazil. Paris: UNESCO.

Wood, C. (1991) 'Categorias Censitarias e Classificações Subjetivas de Raça no Brasil', in P. Lovell Desigualdade Racial no Brasil Contemporâneo, pp. 93-111. Belo Horizonte: MGSP Editores.

STANLEY R. BAILEY is Assistant Professor of Sociology in the Department of Sociology at the University of California, Irvine. Address: UCI Department of Sociology, 3151 Social Science Plaza, Irvine, CA 92697-5100, USA. [email: bailey@uci.edu]

EDWARD E. TELLES is Professor of Sociology in the Department of Sociology at the University of California, Los Angeles. Address: UCLA Department of Sociology, 264 Haines Hall - Box 951551, Los Angeles, CA 90095-1551, USA. [email: telles@soc.ucla.edu] 